\title{
Projetando uma casa com o software sweet home 3D
}

\section{Clarissa Lopes Trojack}

Professora, ULBRA

clarissatrojack@gmail.com

\section{Resumo}

Nesta sugestão de atividade apresentamos três tarefas para a construção de uma planta de casa com visão 2D e 3D usando o programa Sweet Home 3D 3.1 que pode ser baixado gratuitamente da internet. De posse do programa, o aluno manipula suas ferramentas, cria projetos e na última tarefa calcula o custo e quantidade de material para a construção e decoração do mesmo. É uma atividade que busca contextualizar o estudo da geometria.

Palavras-chave: Geometria, Sweet Home 3D, Projeto de uma casa.

\section{Designing a home with the software sweet home 3D}

\begin{abstract}
In this suggestion of activity we present three tasks for the construction of a house plant with 2D and 3D viewing using the Sweet Home 3D 3.1 program which can be downloaded for free in the internet. Armed with the program the student handles his tools, designs and creates the projects and in the last task calculates the cost and quantity of material for the construction and decoration of the same. It is an activity that tries to contextualize the study of geometry.
\end{abstract}

Keywords: Geometry, Sweet Home 3D, Project from one house. 


\section{Introdução}

Este texto propõe-se a descrever uma sugestão de atividade a ser realizada com alunos de Ensino Médio que já tenham conhecimentos prévios de Geometria, ou também, pode ser aplicada com alunos de graduação em Matemática, Arquitetura ou áreas afins.

O objetivo é aplicar os conhecimentos de perímetro, área e volume, ou seja, contextualizar o estudo de Geometria através do projeto de uma casa. Os estudantes ainda terão a oportunidade de adquirir algumas informações sobre construção civil.

A primeira tarefa é propor aos alunos que em casa, baixem o programa livre intitulado "Sweet Home 3D 3.1" no endereço: (http://www.sweethome3d.com/ pt/index.jsp). Na verdade, este programa é utilizado por designer e arquitetos, mas por ter uma interface bastante amigável, pode ser usando por qualquer pessoa que tenha interesse. Ele cria plantas com as dimensões desejadas, os projetos podem ser decorados e mobiliados, além de ser visto em segunda e terceira dimensões.

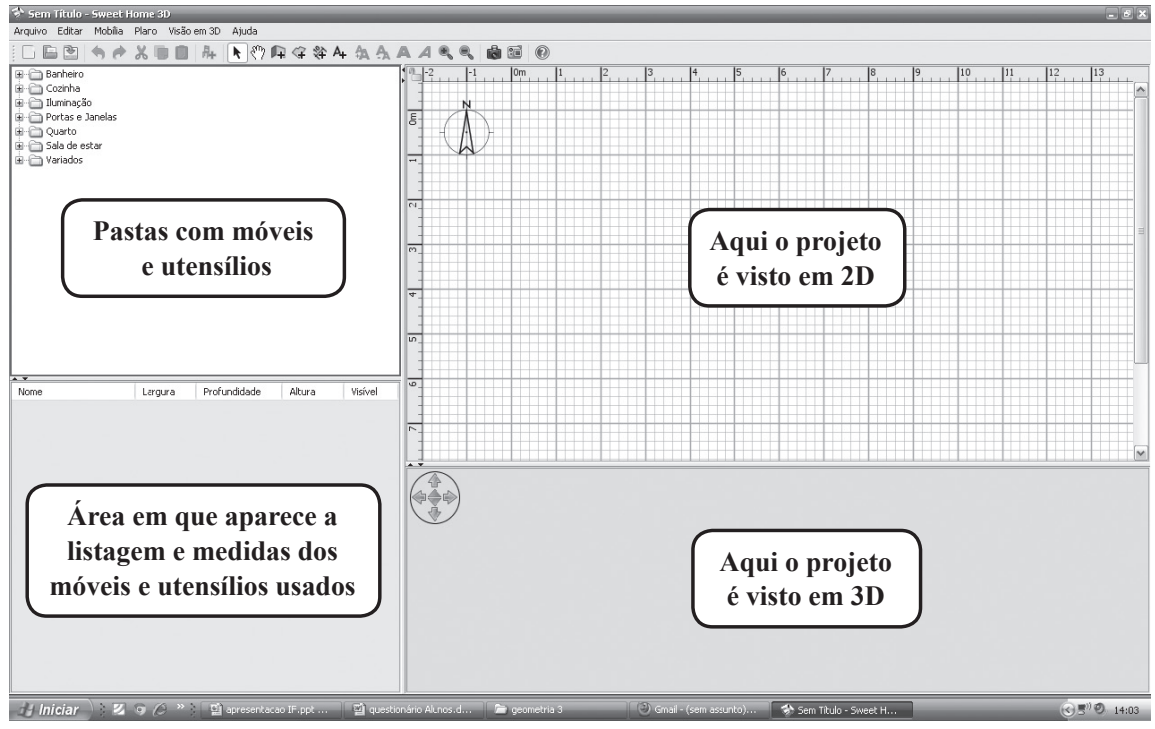

Figura 1 - interface do programa Sweet Home 3D

Com o programa instalado no computador os estudantes devem explorar, manusear e descobrir a função de cada ferramenta. As principais são: criar paredes, criar quartos, criar dimensões, adicionar texto. Ainda apresenta as pastas: 
banheiro, cozinha, iluminação, portas e janelas, quarto, sala de estar e variados. Em cada uma dessas pastas há uma variedade de móveis e utensílios da construção e decoração conforme a figura 1 .

As paredes podem ser pintadas e o piso revestido. Depois deste estudo inicial, pode-se disponibilizar uma aula para socialização, no qual trocam informações e mostram o que descobriram.

Na segunda tarefa, que pode ser em casa ou em aula, solicita-se que criem uma casa com área total em torno de $100 \mathrm{~m}^{2}$, com 3 quartos, 1 sala, 1 cozinha, 1 banheiro e 1 garagem. Caso tenham dificuldades, sugerimos que procurem um tutorial do programa, pois o importante é que o aluno tenha autonomia e criatividade no estudo.



Figura 2 - exemplo de projeto feito por um aluno

$\mathrm{Na}$ terceira tarefa entram os conhecimentos de perímetro, área e volume da Geometria. Para montar as perguntas, consultamos uma pessoa que conhece os termos, quantidades e valores dos materiais de construção.

Apresentamos o seguinte questionário:

A casa deve ter um pé direito ${ }^{1}$ de $2,5 \mathrm{~m}$ com laje. 
1) A casa será coberta com uma laje $\mathrm{e}^{2}$ de $8 \mathrm{~cm}$ de espessura. Calcule o volume de concreto necessário para execução da obra.

2) O concreto é uma mistura de 3 medidas de areia, 3 medidas de brita e 1 medida de cimento. Calcule quantos $\mathrm{m}^{3}$ serão necessários de cada material.

3) Calcular a área $\left(\mathrm{m}^{2}\right)$ de cada peça da casa.
a) Quarto 1
b) Quarto 2
c) Quarto 3
d) Sala
e) Cozinha
f) Banheiro
g) Garagem

4) Os quartos devem ser pintados. Cada lata de tinta tem 3,6 litros e tem um rendimento de aproximadamente $40 \mathrm{~m}$, sendo uma demão. Calcular quantas latas de tinta são necessárias para pintar os quartos com 2 demão?

5) Nos quartos será colocado piso laminado. Quantos $\mathrm{m}^{2}$ ?

6) Na cozinha e garagem será colocado piso cerâmico no chão no valor de $\mathrm{R} \$$ $10,90 \mathrm{o} \mathrm{m}^{2}$. Qual será o custo?

7) No banheiro será colocado revestimento igual nas paredes e chão. Quantos $\mathrm{m}^{2}$ serão necessários e qual o custo sabendo que o $\mathrm{m}^{2}$ custa $\mathrm{R} \$ 12,75$.

8) Quantos metros de rodapé serão necessários para a casa sendo que na cozinha e banheiro não serão utilizados?

Observe que com essas perguntas contemplamos o conhecimento de volume na pergunta 1; regra de três nas perguntas $2,4,6$ e 7; cálculo de área nas perguntas $3,5,6$ e 7 ; e perímetro na pergunta 8 . 


\section{Considerações e recomendações}

A atividade é interessante de ser trabalhada, porque apresenta três etapas relevantes. A primeira em que o aluno precisa baixar o programa, instalá-lo no seu computador e investigá-lo por conta própria. Ainda hoje, muitos professores somente trabalham programas conhecidos anteriormente por eles, e que dominam perfeitamente, mas com essa atividade é diferente, pois os alunos trabalham sem a interferência do professor. Percebe-se a autonomia e a busca da resolução das dificuldades pelo próprio estudante.

Na segunda tarefa, em que os jovens já descobriram a função de cada ferramenta, e até já devem ter criado algumas plantas, é a vez de verificar sua criatividade, bom gosto e estética na criação de uma casa previamente planejada pelo professor. Nesta fase aconselha-se a lembrá-los da posição das janelas, da disposição dos quartos, sala, cozinha, para que a casa seja funcional e bonita, exatamente como um arquiteto pensaria. Mesmo o projeto tendo algumas restrições dadas pelo professor, tais como: "A casa deve ter uma área em torno de $100 \mathrm{~m}^{2}$ ”, cada aluno terá ao final da atividade um projeto diferente e medidas também diferentes.

E na terceira tarefa os estudantes usam a Matemática presente no cotidiano e que poderá ser muito útil em outros momentos de suas vidas. Ainda é possível, com as atividades, descobrir talentos e apresentar-lhes a profissão de designer, arquiteto e decorador.

Submetido em maio de 2012

Aprovado em junho de 2012 